Article

\title{
Buckling Analysis of Pultruded Glass Fiber Reinforced Polymer (GFRP) Angle Sections
}

\author{
Rahima Shabeen Sirajudeen * and Rajesh Sekar \\ College of Engineering Guindy, Anna University, Tamil Nadu 600025, India; rajeshsekar91@gmail.com \\ * Correspondence: rahima@annauniv.edu; Tel.: +91-44-22357404
}

Received: 8 October 2020; Accepted: 27 October 2020; Published: 29 October 2020

\begin{abstract}
Glass fiber reinforced polymers (GFRP), with their advantage of corrosion resistance, have potential to be used as structural members in civil engineering constructions. Pultruded GFRP angle section trusses could be used instead of steel sections in remote areas and in areas prone to corrosion. The objective of this paper is to study the strength of GFRP angle sections under concentric axial load. Glass fiber reinforced polymer (GFRP) made of E-glass and Isophthalic polyester resin and manufactured by pultrusion process was used for the experimental study. Two GFRP angle sections of size $50 \times 50 \times 6 \mathrm{~mm}$ and $50 \times 50 \times 4 \mathrm{~mm}$ and lengths $500 \mathrm{~mm}, 750 \mathrm{~mm}$, and $1000 \mathrm{~mm}$ were chosen for the study. Further, finite experimental element analysis of the GFRP angle sections was done using ANSYS software and validated with the experimental results. The validated FE model was used for parametric studies varying the slenderness ratio and flange width to thickness ratio $(\mathrm{b} / \mathrm{t})$ ratio. It was observed that length of the specimen and thickness influenced the buckling load and buckling mode. An increase in $b / t$ ratio from 8.3 to 12.5 decreases the load carrying capacity by almost $60 \%$ at a slenderness ratio of 50 .
\end{abstract}

Keywords: pultruded glass-fiber reinforced polymer; angle columns; axial compression; buckling

\section{Introduction}

Use of fiber reinforced polymer (FRP) in civil structural applications has been constantly increasing owing to its advantageous properties of greater corrosion resistance, low maintenance requirement and high durability even in aggressive environments when compared to the traditional construction materials like steel and reinforced concrete. FRP have potential to be used as an alternative construction material in offshore constructions, chemical plants, and transmission line towers. However, the FRP are also heterogenous, orthotropic, brittle, and not ductile when compared to steel which is homogeneous, isotropic, and ductile. Hence, the well-established theories and concepts used for design of structural steel elements cannot be used as such for FRP member. There is a need for a thorough investigation on the behavior of a FRP member to derive reliable design equations.

Angle sections are typically used as truss members in towers and are subjected to axial tension or compression and are traditionally made of steel. Fewer studies are available on GFRP angle section as compared to studies on GFRP I sections [1] and there is a lack of reliable design standards on angle sections for design engineers [2].

Many researchers have studied the behavior pultruded FRP sections of different shapes namely angle shaped sections [2-4], I shaped sections [5-13], Channel [14,15], box [16,17], and tubular sections [18]. Barbero and Tombli [5,6] investigated critical load of long GFRP I-section columns. A simplified method based on Southwell's method based on Eulers buckling was used to determine the critical buckling load. Hashem and Yuan [16] conducted axial compressive strength studies on GFRP composite universal and box section columns manufactured by pultrusion process using E-glass fibers and polyester and vinylester resins. Euler' s formula was employed to obtain critical loads for the 
slender columns. The classical plate theory was used to predict buckling load of short columns. Based on experimental evaluations and analytical results, a slenderness-ratio-based criterion was established for distinguishing between short and long composite column behaviors. Cardoso et al. [17] developed compressive strength equations for box columns considering global slenderness, plate slenderness, and imperfection factor. Laudiero et al. [19] investigated the sensitivity of initial imperfections for wide and narrow flange I-section columns under pure compression. Cintra et al. [20] studied the performance and strength of pultruded GFRP stub columns subjected to short term concentric loading.

Research papers are also available on the application of FRP pultruded sections in transmission line towers. Godat et al. [1] investigated the replacement of traditional materials (steel, wood, and concrete) in electricity transmission lines by fiber glass pultruded members. Various cross-sections made of E-glass and either polyester or vinylester matrix were tested. Angle-section, square-section, and rectangular-section specimens were subjected to axial compression and I-section and $\mathrm{W}$-section specimens were tested under bending. The experimental results were summarized in terms of the failure mode, critical buckling load, and load-displacement relationships. Design equations available in FRP design manuals and analytical methods proposed in the literature were used to predict the critical buckling load. Selvaraj et al. [21] successfully tested a $66 \mathrm{kV}$ transmission line tower made with GFRP composite angle sections. Selvaraj [22] conducted experiments on X-braced panel of transmission line tower made from FRP pultruded sections. Mathematical model of individual members and members in the X-braced panel were generated using FEM software. Prasad Rao et al. [2] investigated the failure of full-scale $24 \mathrm{~m}$ triangular lattice GFRP communication tower. Experimental, analytical and numerical studies were conducted on GFRP angles subjected to axial compression. Further the behavior of GFRP $60^{\circ}$ and $90^{\circ}$ angles in lattice system were studied and it was observed that the reason for failure of the $60^{\circ}$ angle tower was the flexural-torsional buckling of leg member. Balagopal et al. [23] carried out experimental investigation on X-braced Transmission line tower substructure and observed that the tower failed prematurely due to the excessive bending stress exerted on the free length of stub member.

It is observed from literature that buckling is the dominant mode of failure in the experimental studies as opposed to crushing failure because of the reduced modulus of GFRP members. Buckling observed was either flexural buckling, flexural-torsional buckling, or local buckling depending on the shape, geometry, and length of the section. Theoretical studies have also been done to establish equations to predict the buckling loads of these members based on Euler global buckling equations and plate buckling equations for flexural, flexural-torsional buckling and local buckling.

In the present study, buckling analysis of pultruded GFRP angle sections subjected to concentric axial load is carried out using Finite element analysis software ANSYS. The scope of the study includes: (i) Experimental study on GFRP angle section of different slenderness ratio and width-to-thickness ratio; (ii) developing a finite element model in ANSYS; (iii) validation of finite element analysis results with experimental results of [3] and with the results of the experimental study carried out at College of Engineering Guindy, Anna University; and (iv) conducting a parametric study using the validated Finite Element Model (FEM) varying the slenderness and width-to-thickness ratio of the GFRP angle section.

\section{Finite Element Analysis}

Numerical study on the buckling behavior of angle section was done using Finite Element Method (FEM). The angle sections were modeled by using ANSYS FE software and compared with the experimental results of [3]. The angle section was of size $102 \times 102 \times 12.7 \mathrm{~mm}(\mathrm{~b} \times \mathrm{b} \times \mathrm{t})$ and length $1524 \mathrm{~mm}$. GFRP material was assumed to be linear, elastic and orthotropic in the FE model. The material properties of the section are longitudinal modulus $\left(\mathrm{E}_{\mathrm{L}}\right)=20.8 \mathrm{GPa}$, In-plane shear modulus $\left(\mathrm{G}_{\mathrm{L}}\right)=3.3 \mathrm{GPa}$, longitudinal strength $\left(\mathrm{F}_{\mathrm{LC}}\right)=308 \mathrm{MPa}$ and In-plane shear strength $=68 \mathrm{MPa}$. "SHELL181" quadrilateral element was used to model the GFRP angle sections. "SHELL 181" is a four-noded element with six degrees of freedom at each node. It has linear/nonlinear and large rotation capabilities and can be used to model composite materials. The geometry of the angle section was 
automatically meshed by using mapped meshing algorithm. The end constrains at the extremities were modelled to represent simply supported boundary conditions. The bottom extremity of the angle section was restrained against all translational motions and the top extremity was also restrained against all translational motion except in the longitudinal direction. Material failure criteria was not specified as material crushing was a not predominant mode of failure and this study focusses on buckling behavior of the sections. A vertical load of unit total magnitude was applied at the nodes at the extremity of the column. The eigenvalue solution was obtained using the block Lanczos algorithm in ANSYS software. Buckling load and buckling mode shape of the angle section obtained from finite element analysis are compared with experimental results of Zureick and Steffen [3]. Table 1 shows the Finite Element Analysis (FEA) and experiment [3] results. Figure 1 shows the buckled mode shape of FEA and experiment [3]. It is observed from Figure 1 and Table 1 that the FEA is in good correspondence with experiment results [3].

Table 1. Ultimate strength of glass fiber reinforced polymers (GFRP) angle sections.

\begin{tabular}{cccccccc}
\hline S.No. & $\begin{array}{c}\text { Size of GFRP } \\
\text { Angle Section }\end{array}$ & $\begin{array}{c}\text { Length } \\
(\mathbf{m m})\end{array}$ & $\begin{array}{c}\text { Longitudinal Modulus } \\
\text { of Elasticity (MPa) }\end{array}$ & $\boldsymbol{b} / \boldsymbol{t}$ & $\boldsymbol{l} / \boldsymbol{r}$ & \multicolumn{2}{c}{ Buckling Load (kN) } \\
\cline { 6 - 8 } & $\begin{array}{c}102 \times 102 \times \\
12.5\end{array}$ & 152 & 50.50 & 8 & 79 & $56 \mathrm{kN}$ & $64.4 \mathrm{kN}$ \\
\hline
\end{tabular}

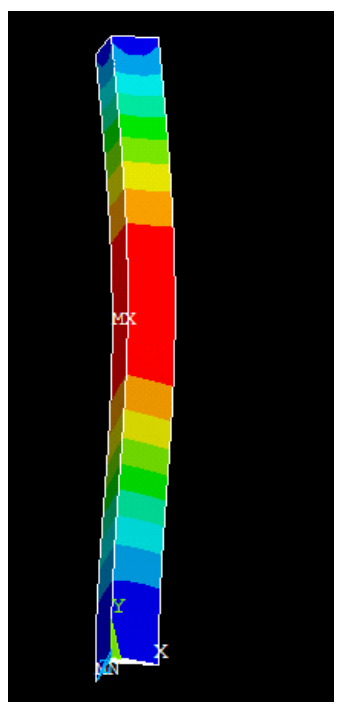

(a)

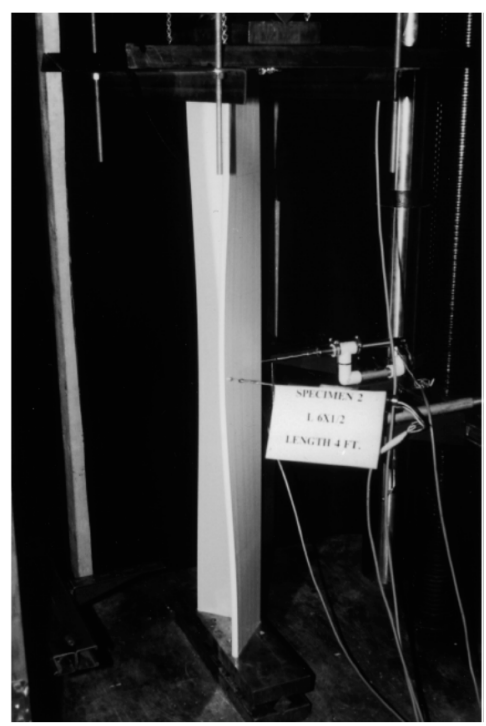

(b)

Figure 1. Buckling mode shape validation (a) Finite Element Analysis; (b) experiment Zureick and Steffen [3].

\section{Experimental Program}

Two sizes of angle sections namely $50 \times 50 \times 4 \mathrm{~mm}(\mathrm{~b} \times \mathrm{b} \times \mathrm{t})$ and $50 \times 50 \times 6 \mathrm{~mm}(\mathrm{~b} \times \mathrm{b} \times \mathrm{t})$ and lengths $1000 \mathrm{~mm}, 750 \mathrm{~mm}$, and $500 \mathrm{~mm}$ were chosen for the experimental study based on sections available in the market. Figure 2 shows the cross-section of a typical angle section.

GFRP angle sections were manufactured by pultrusion process and made of E-glass and polyester isophthalic resin. The tensile properties of GFRP angle sections as per ASTM standard D638-14 were tested at a loading rate of $1 \mathrm{~mm} / \mathrm{min}$ in Universal Testing Machine (INSTRON) of capacity $50 \mathrm{kN}$ available at Advanced Material Testing Laboratory in Central Workshop Division. Maximum tensile strength was found to be $487.2 \mathrm{MPa}$ and corresponding ultimate strain was 0.134 . Modulus of elasticity in the major direction was found to be $8897 \mathrm{MPa}$. Figure 3a,b show the test setup and the stress 
strain curve of GFRP coupons respectively. Volume fraction of fiber was determined as per ASTM D3171-99(04). The fiber volume content of GFRP specimen was found to be $66.67 \%$.

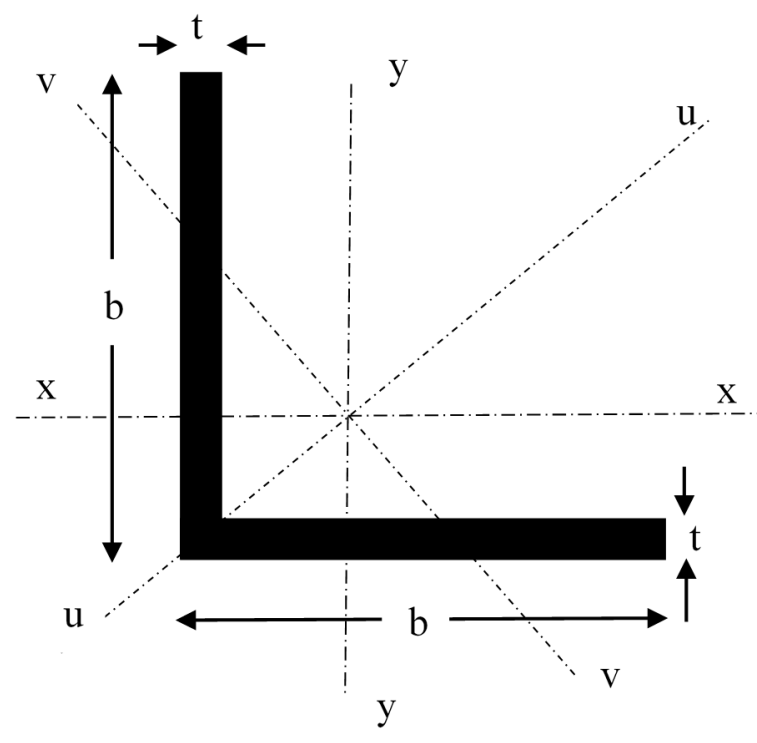

Figure 2. Geometry of angle section.

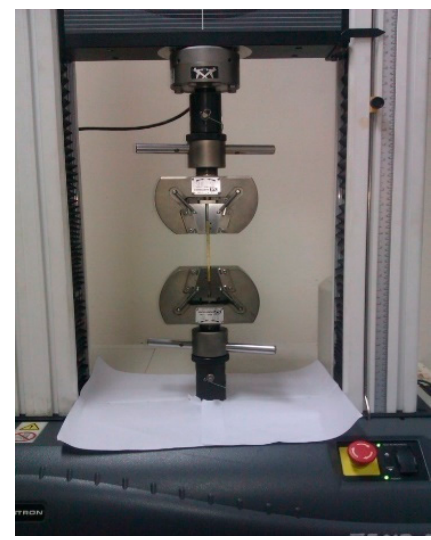

(a)

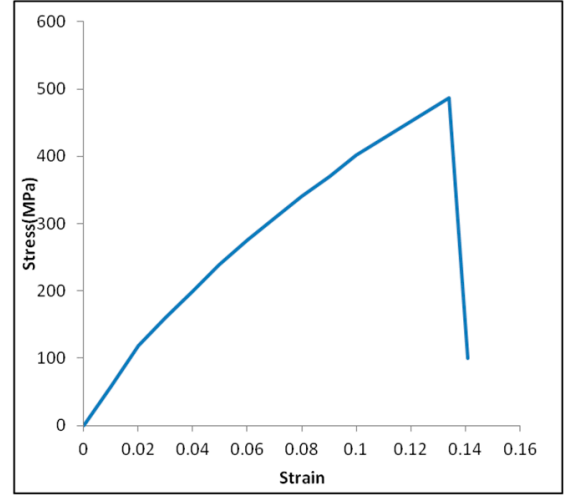

(b)

Figure 3. (a) Tensile test of GFRP coupon; (b) stress-strain curve of GFRP.

Geometric properties of the selected angle sections are shown in Table 2. GFRP angle sections were tested under axial load using hydraulic jack of capacity $10 \mathrm{t}$. Spreader plates were kept at the ends to apply vertical load uniformly over the cross-section. Grooved plates were placed at the extremity of the GFRP angle sections to prevent lateral motion at the ends. Experimental setup is illustrated in Figure 4. The GFRP angle sections were tested up to failure. Axial load, axial deformation, and strains were recorded.

Table 2. Geometry of the glass fiber reinforced polymer (GFRP) angle sections.

\begin{tabular}{|c|c|c|c|c|c|c|c|c|c|}
\hline \multirow{2}{*}{$\begin{array}{l}\text { FRP Angle Section } \\
(\mathrm{mm})\end{array}$} & \multirow{2}{*}{$\begin{array}{l}\text { Section Area } \\
\qquad\left(\mathrm{mm}^{2}\right)\end{array}$} & \multirow{2}{*}{$\begin{array}{l}\text { Centre of Gravity } C_{x x}, C_{y y} \\
(\mathrm{~mm})\end{array}$} & \multicolumn{3}{|c|}{$\begin{array}{c}\text { Radius of Gyration } \\
\text { (mm) }\end{array}$} & \multicolumn{4}{|c|}{$\begin{array}{l}\text { Moment of Inertia } \\
\quad \times 10^{4}\left(\mathrm{~mm}^{4}\right)\end{array}$} \\
\hline & & & $r_{x x}, r_{y y}$ & $\mathbf{r}_{\mathrm{uu}}$ & $\mathbf{r}_{\mathrm{vv}}$ & $\mathbf{I}_{\mathbf{x}}, \mathbf{I}_{\mathbf{y y}}$ & $\mathbf{I}_{\mathrm{uu}}$ & $\mathbf{I}_{\mathrm{vv}}$ & $\mathbf{I}_{\mathbf{x y}}$ \\
\hline $50 \times 50 \times 4$ & 384 & 13.9 & 15.5 & 19.5 & 9.9 & 9.26 & 14.7 & 3.8 & 5.5 \\
\hline $50 \times 50 \times 6$ & 564 & 14.7 & 15.2 & 19.2 & 9.8 & 13.1 & 20.8 & 5.4 & 7.7 \\
\hline
\end{tabular}




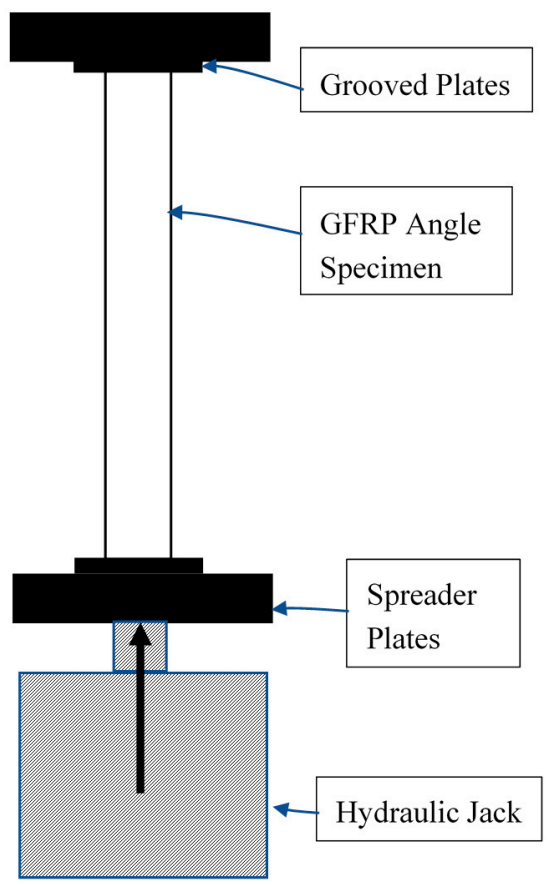

Figure 4. Experimental loading setup.

\section{Results and Discussions}

\subsection{Experimental Results}

All the GFRP angle sections were tested up to failure. Strength of the GFRP angle sections is tabulated in Table 3.

Table 3. Ultimate strength of GFRP angle sections.

\begin{tabular}{|c|c|c|c|c|c|c|}
\hline \multirow{2}{*}{ S.No. } & \multirow{2}{*}{$\begin{array}{l}\text { Size of GFRP } \\
\text { Angle Section }\end{array}$} & \multirow{2}{*}{ Length (mm) } & \multirow{2}{*}{$\begin{array}{c}\text { Slenderness } \\
\text { Ratio }\end{array}$} & \multicolumn{2}{|c|}{ Ultimate Strength (kN) } & \multirow{2}{*}{$\mathbf{P}_{\text {FEA }} / \mathbf{P}_{\text {EXP }}$} \\
\hline & & & & Experiment $\left(\mathrm{P}_{\mathrm{EXP}}\right)$ & FEA $\left(P_{\text {FEA }}\right)$ & \\
\hline 1 & $50 \times 50 \times 4 \mathrm{~mm}$ & 500 & 50.50 & 11.56 & 13.92 & 1.204 \\
\hline 2 & $50 \times 50 \times 4 \mathrm{~mm}$ & 750 & 75.75 & 7.85 & 8.31 & 1.059 \\
\hline 3 & $50 \times 50 \times 6 \mathrm{~mm}$ & 500 & 51.00 & 27.00 & 28.83 & 1.068 \\
\hline 4 & $50 \times 50 \times 6 \mathrm{~mm}$ & 750 & 76.50 & 21.56 & 22.68 & 1.052 \\
\hline 5 & $50 \times 50 \times 6 \mathrm{~mm}$ & 1000 & 102.00 & 18.15 & 19.92 & 1.098 \\
\hline \multirow{2}{*}{\multicolumn{6}{|c|}{$\begin{array}{c}\text { Mean } \\
\text { Standard Deviation }\end{array}$}} & 1.096 \\
\hline & & & & & & 0.0563 \\
\hline
\end{tabular}

Failure of GFRP Angle Sections

GFRP angles of size $50 \times 50 \times 6 \mathrm{~mm}$ and lengths $1000 \mathrm{~mm}$ and $750 \mathrm{~mm}$ exhibited behavior of opening of the flanges near the mid-height, twisting of the cross-section, and overall bending which is shown in Figure $5 \mathrm{a}, \mathrm{b}$ respectively. The failure of the specimens was by rupture of the fabric at the flange junction. GFRP angle of size $50 \times 50 \times 6 \mathrm{~mm}$ and length $500 \mathrm{~mm}$ exhibited behavior of closing of the flanges near the support and slight twisting. No marked bending of the specimen was observed. The failure was by rupture of fibers in one of the flanges Figure $5 \mathrm{c}$. Behavior of GFRP angle of size $50 \times 50 \times 4 \mathrm{~mm}$ was similar to that of GFRP angles $50 \times 50 \times 6 \mathrm{~mm}$. GFRP angle of size $50 \times 50 \times 4 \mathrm{~mm}$ and length $1000 \mathrm{~mm}$ and $750 \mathrm{~mm}$ failed by rupture of the fabric at the flange junction which is shown in Figure $6 \mathrm{a}, \mathrm{b}$ respectively. GFRP angles $50 \times 50 \times 4 \mathrm{~mm}$ of length $500 \mathrm{~mm}$ failed by rupture of the fibers near the support as shown in Figure 6c. 


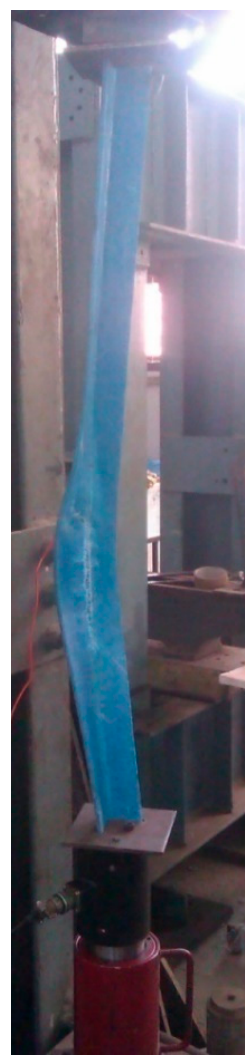

(a) Length $=1 \mathrm{~m}$

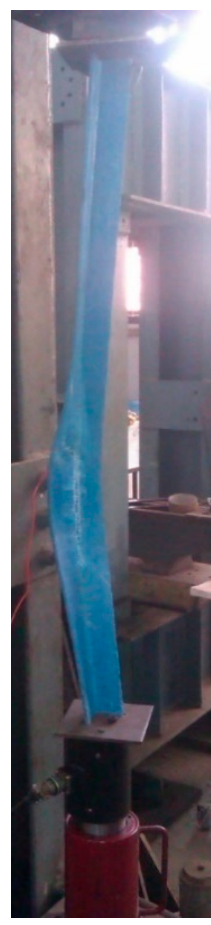

(b) Length $=0.75 \mathrm{~m}$

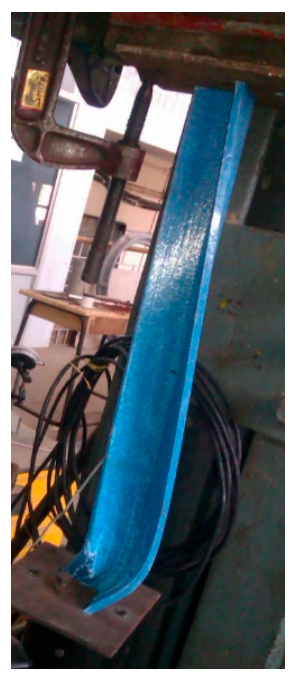

(c) Length $=0.5 \mathrm{~m}$

Figure 5. Buckling behavior of GFRP angle sections $50 \mathrm{~mm} \times 50 \mathrm{~mm} \times 6 \mathrm{~mm}$.

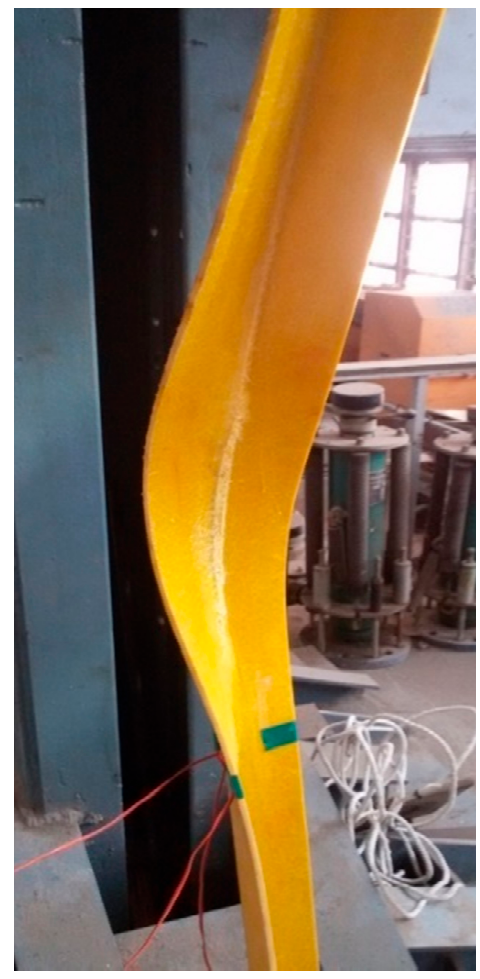

(a) Length $=1 \mathrm{~m}$

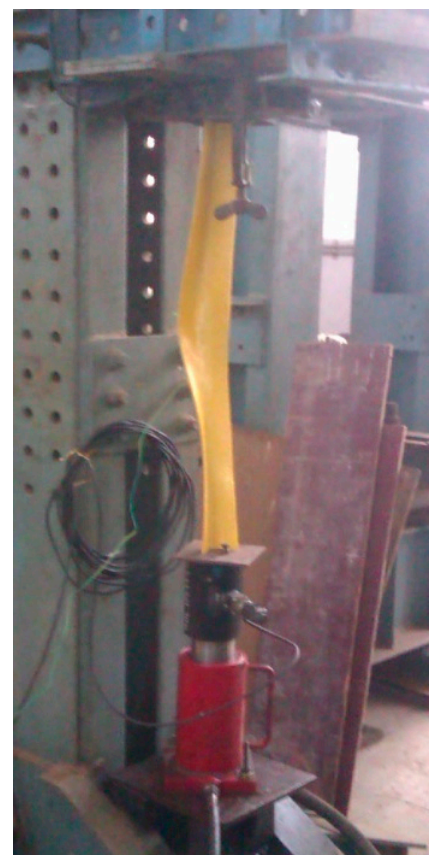

(b) Length $=0.75 \mathrm{~m}$

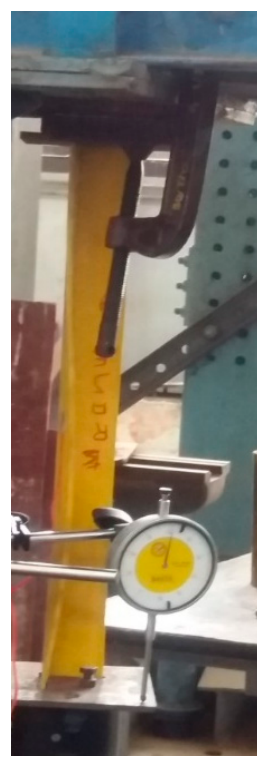

(c) Length $=0.5 \mathrm{~m}$

Figure 6. Buckling behavior of GFRP angle sections $50 \mathrm{~mm} \times 50 \mathrm{~mm} \times 4 \mathrm{~mm}$. 
Specimens failed by rupture of GFRP and no marked delamination were observed. All specimens gave warning before failure in the form of noise. The failed specimens returned back to their original geometry on removal of load.

It is observed that the though the modes of failure is similar for sections $50 \mathrm{~mm} \times 50 \mathrm{~mm} \times 6 \mathrm{~mm}$ $(b / t=8.33)$ and $50 \mathrm{~mm} \times 50 \mathrm{~mm} \times 4 \mathrm{~mm}(b / t=12.5)$, the ultimate strength is greatly reduced. Ultimate load reduces by about $60 \%$ when the $\mathrm{b} / \mathrm{t}$ ratio is increased from 8.33 to 12.5 .

\subsection{Finite Element Analysis}

The tested GFRP angle sections were modelled in ANSYS. A linear elastic orthotropic constitutive law has been adopted for the pultruded FRP material. The material properties based on tensile test and based on properties provided by the manufacturer were input to the model. "SHELL181" quadrilateral element was used to model the GFRP angle sections. "SHELL 181" is capable of large rotation capabilities. Automatic mapped meshing was applied to mesh the geometry. Simply supported boundary conditions were ensured at the extremity by restraining the translational motions. The predominant mode of failure observed during experimental studies was buckling. Hence, buckling analysis using block Lanczos algorithm in ANSYS software was the focus of the simulation. Failure criteria were not adopted in the analysis, in order to give importance to the study of global aspects of the member behavior.

The critical buckling loads and associated mode shapes were obtained from linear buckling analysis. A comparison of the buckling load and buckling pattern with that of the experimental results were made. Table 3 shows the comparison of buckling loads between finite element analysis and experiments. It was observed that the FE results vary from the experimental results by 5-6\%. Figure 7 shows the comparison of buckling pattern between finite element analysis and experiments for slenderness ratios 50 and 100. It is observed that the numerical results based on Finite Element Analysis (FEA) are in good agreement with the experimental results.

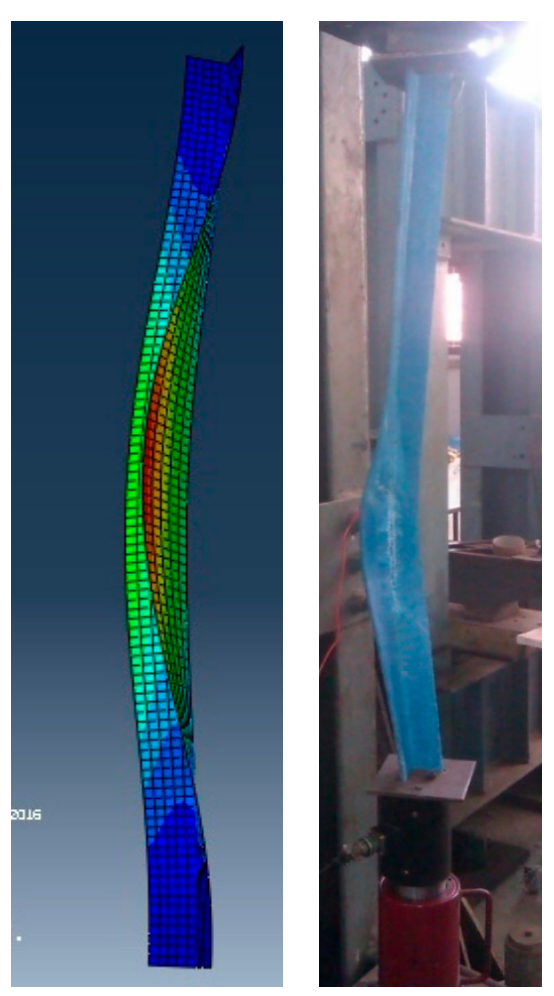

(a) Slenderness ratio $=100$
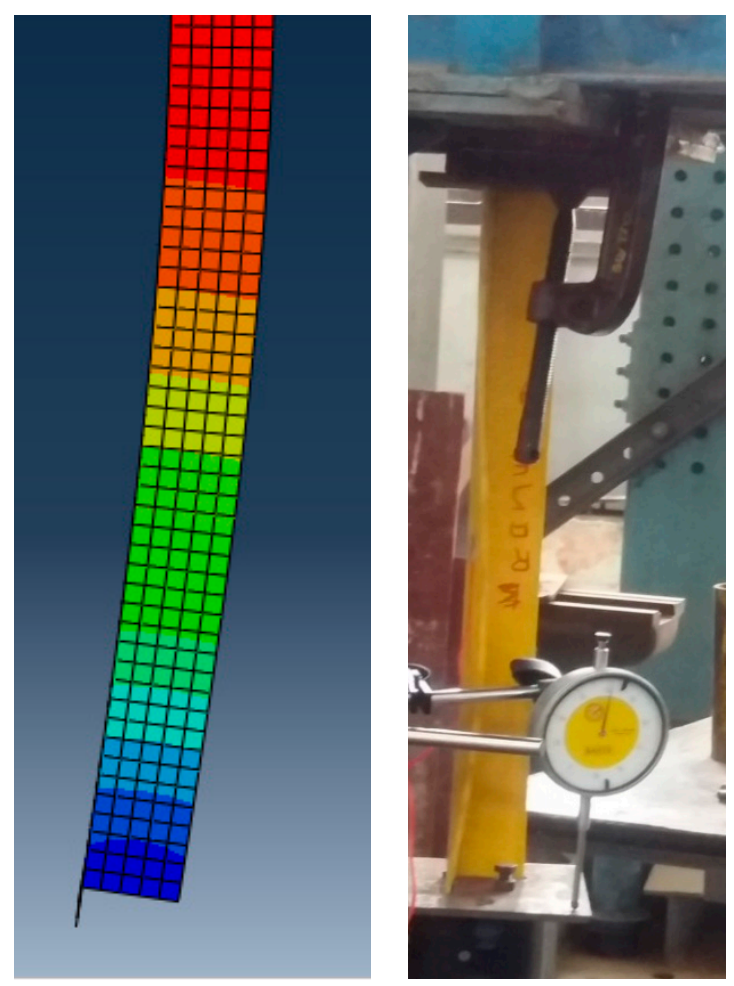

(b) Slenderness ratio $=50$

Figure 7. Buckling pattern-Experiment and Finite Element Analysis (FEA). 


\subsection{Effect of Width-To-Thickness Ratio}

It was observed from the experimental study that the thickness of the section and length of the member influences the buckling load. Hence, a parametric study is done varying the width to thickness ratio and slenderness ratio of the angle section.

The width of the section was kept constant and the thickness of the section was varied from $3 \mathrm{~mm}$ to $10 \mathrm{~mm}$ corresponding to width-to-thickness ratio $(b / t)$ of 16.67 to 5 [Table 4]. The length of the section was also varied from $500 \mathrm{~mm}$ to $1000 \mathrm{~mm}$ corresponding to the slenderness ratios of about 50 to 100 .

Table 4. Size of angle sections considered for parametric study.

\begin{tabular}{cccc}
\hline $\begin{array}{c}\text { Size of the GFRP Angle } \\
\text { Section }(\mathbf{m m})\end{array}$ & $\begin{array}{c}\text { Width-To-Thickness } \\
\text { Ratio }(\boldsymbol{b} / \boldsymbol{t})\end{array}$ & $\begin{array}{c}\text { Area of Cross-Section } \\
\left(\mathbf{m m}^{\mathbf{2}}\right)\end{array}$ & $\begin{array}{c}\text { Least Radius of } \\
\text { Gyration }(\mathbf{m m})\end{array}$ \\
\hline $50 \times 50 \times 3$ & 16.7 & 291 & 9.95 \\
$50 \times 50 \times 4$ & 12.5 & 384 & 9.88 \\
$50 \times 50 \times 5$ & 10.0 & 475 & 9.83 \\
$50 \times 50 \times 6$ & 8.3 & 564 & 9.79 \\
$50 \times 50 \times 7$ & 7.1 & 651 & 9.76 \\
$50 \times 50 \times 8$ & 6.3 & 736 & 9.74 \\
$50 \times 50 \times 9$ & 5.6 & 819 & 9.73 \\
$50 \times 50 \times 10$ & 5.0 & 900 & 9.73 \\
\hline
\end{tabular}

Figure 8 shows the variation of buckling load with slenderness ratio for various width-to-thickness ratio. It is observed from Figure 8 that the buckling load decreases with increase in slenderness ratio. The rate of decrease of buckling load increases with the decrease in width-to-thickness ratio $(b / t)$ ratio.

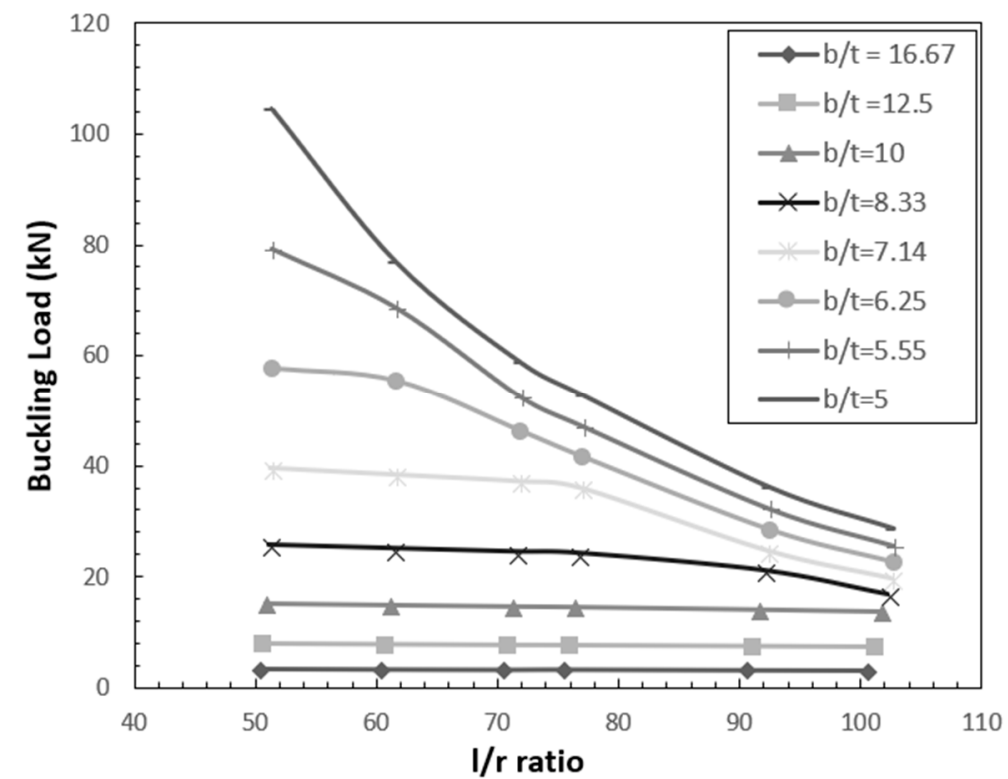

Figure 8. Effect of slenderness ratio and width-to-thickness ratio on buckling load.

The stress at buckling load was calculated from the buckling load and the variation of stress with slenderness ratio for various width-to-thickness ratio is plotted in Figure 9. It is observed that the buckling load reduces to up to $10 \%$ when the width-to-thickness $(b / t)$ varies from 5 to 16.7 . Figure 10 shows the variation of buckling load with width-to-thickness ratio for various slenderness ratios. It is observed that beyond a width-to-thickness ratio of 10, the buckling load of the section is independent of the slenderness ratio. 


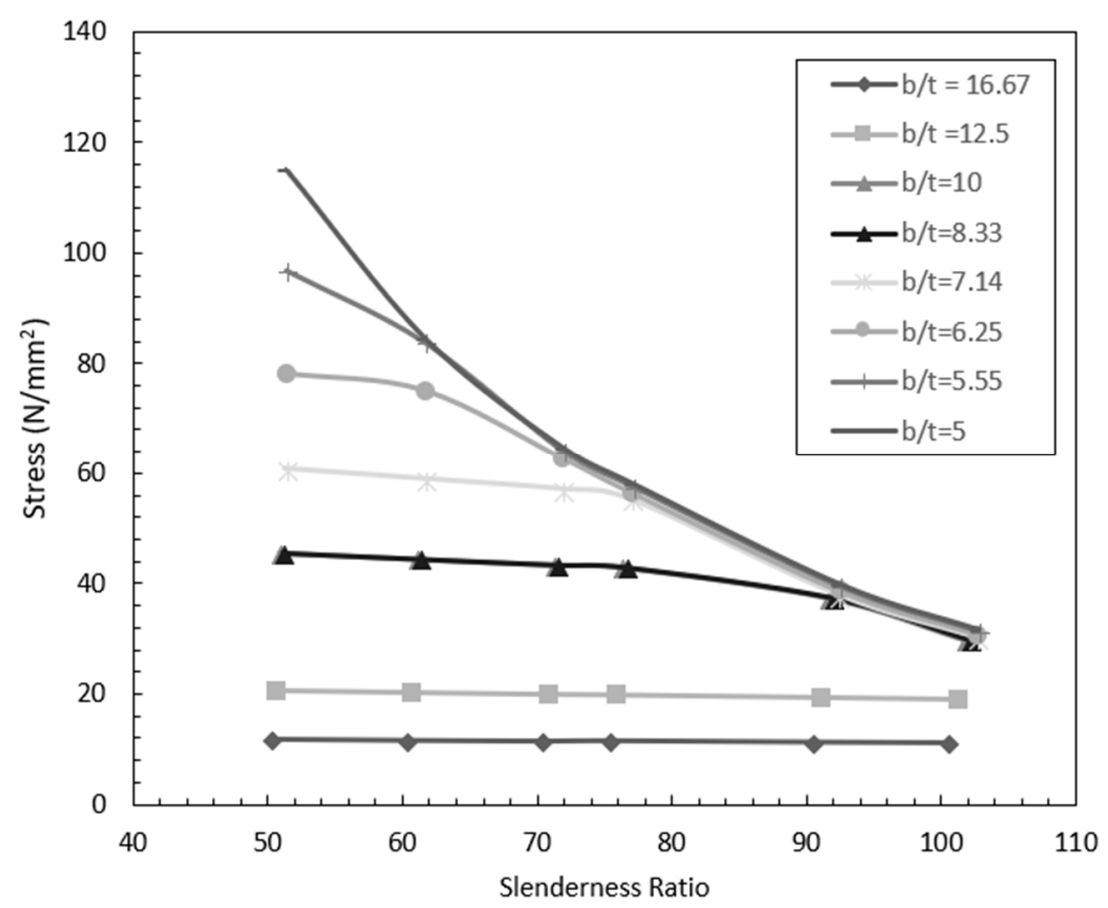

Figure 9. Variation of stress at buckling load with slenderness ratio and width-to-thickness ratio.

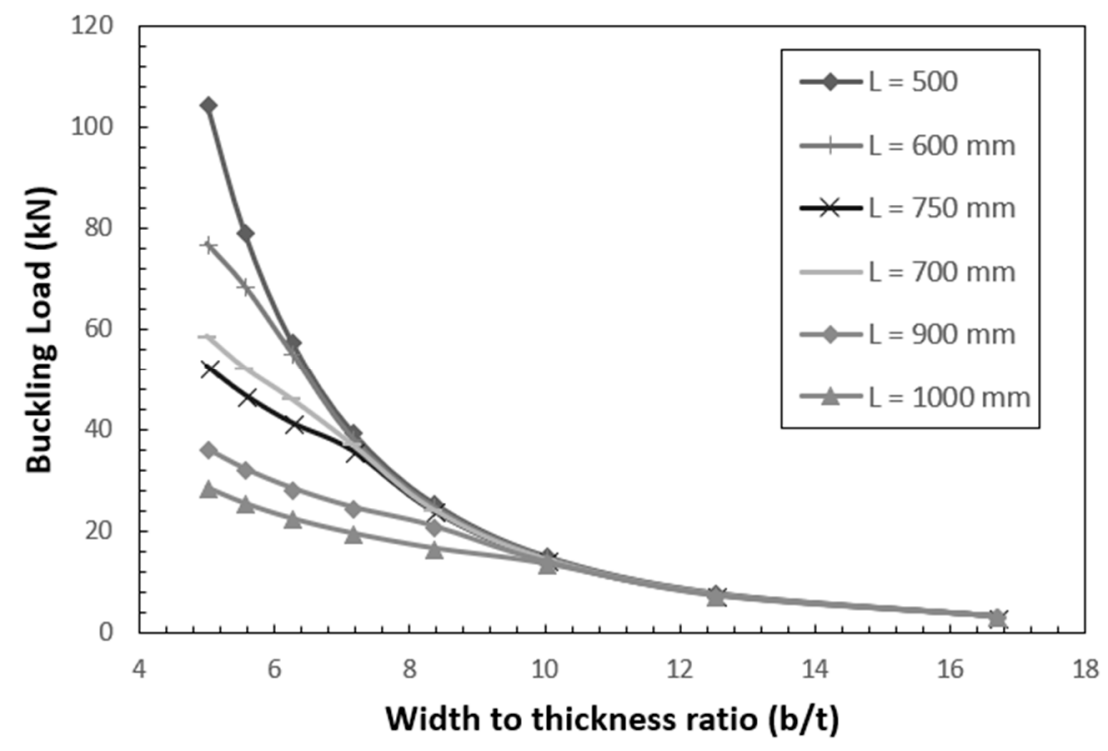

Figure 10. Effect of width-to-thickness ratio on buckling load.

\section{Conclusions}

In this paper, an experimental and numerical study is carried out on the buckling response of GFRP angle sections of varying thickness and length to bring out the influence of these geometric parameters on the buckling strength and buckling mode. The study involved testing of GFRP angle columns under concentric axial load and development of Finite Element Model (FEM) using ANSYS.

Based on the study on GFRP angle sections under concentric axial compression, the following conclusions are made:

- Specimens of length $750 \mathrm{~mm}$ and $1000 \mathrm{~mm}$ buckled in overall flexural buckling mode with opening of the flanges. The failure was by rupture of fibers at the junction of the two flanges at mid height. 
- Specimens of length $500 \mathrm{~mm}$ failed by torsional buckling with closing of the flanges near the loading end. The failure was by rupture of fibers in one of the flanges.

- Based on experimental study, it is observed that an increase in $b / t$ ratio from 8.3 to 12.5 decreases the load carrying capacity by about $60 \%$.

- Developed finite element model compares well with the experimental study.

- Based on the parametric study, it is observed that the buckling strength decreases with increase in slenderness ratio and width-to-thickness ratio.

- The influence of width-to-thickness ratio is more at lower slenderness ratios. However the study was limited to GFRP angles in the slenderness range of 50 to 100. Future studies can include slenderness ratios beyond these values to have a better understanding of the behavior.

Author Contributions: Conceptualization, R.S.S. and R.S.; methodology, R.S.S. and R.S.; software, R.S.; validation, R.S.; formal analysis, R.S.S. and R.S.; investigation, R.S.; resources, R.S.S. and R.S.; data curation, R.S.S. and R.S.; writing - original draft preparation, R.S. and R.S.S.; writing—review and editing, R.S.S.; visualization, R.S.S. All authors have read and agreed to the published version of the manuscript.

Funding: This research received no external funding.

Acknowledgments: The authors gratefully acknowledge the Department of Civil Engineering, Anna University for providing the laboratory facilities to conduct the experiments. Axial load test on GFRP angles were conducted at Structural Dynamics Laboratory, Division of Structural Engineering, Department of Civil Engineering, Anna University, Chennai, India.

Conflicts of Interest: The authors declare no conflict of interest.

\section{References}

1. Godat, A.; Légeron, F.; Gagné, V.; Marmion, B. Use of FRP pultruded members for electricity transmission towers. Compos. Struct. 2013, 105, 408-421. [CrossRef]

2. Prasad Rao, N.; Rokade, R.P.; Balagopal, R. Failure investigation of GFRP communication towers. Eng. Fail. Anal. 2017, 79, 397-407. [CrossRef]

3. Zureick, A.; Steffen, R. Behavior and design of concentrically loaded pultruded angle struts. J. Struct. Eng. N. Y. 2000, 126, 406-416. [CrossRef]

4. Cardoso, D.C.T.; Togashi, B.S. Experimental investigation on the flexural-torsional buckling behavior of pultruded GFRP angle columns. Thin-Walled Struct. 2018, 125, 269-280. [CrossRef]

5. Barbero, E.; Tomblin, J. Euler buckling of thin-walled composite columns. Thin-Walled Struct. 1993, 17, 237-258. [CrossRef]

6. Barbero, E.; Tomblin, J. A phenomenological design equation for FRP columns with interaction between local and global buckling. Thin-Walled Struct. 1994, 18, 117-131. [CrossRef]

7. Pecce, M.; Cosenza, E. Local buckling curves for the design of FRP profiles. Thin-Walled Struct. 2000, 37, 207-222. [CrossRef]

8. Mottram, J.T. Determination of critical load for flange buckling in concentrically loaded pultruded columns. Compos. Part B Eng. 2004, 35, 35-47. [CrossRef]

9. Ragheb, W.F. Local buckling analysis of pultruded FRP structural shapes subjected to eccentric compression. Thin-Walled Struct. 2010, 48, 709-717. [CrossRef]

10. Nunes, F.; Correia, M.; Correia, J.R.; Silvestre, N.; Moreira, A. Experimental and numerical study on the structural behavior of eccentrically loaded GFRP columns. Thin-Walled Struct. 2013, 72, 175-187. [CrossRef]

11. Cardoso, D.C.T.; Harries, K.A.; Batista, E.D.M. Compressive local buckling of pultruded GFRP I-sections: Development and numerical/experimental evaluation of an explicit equation. J. Compos. Constr. 2015, 19. [CrossRef]

12. Nunes, F.; Correia, J.R.; Silvestre, N. Structural behaviour of hybrid FRP pultruded columns. Part 1: Experimental study. Compos. Struct. 2016, 139, 291-303. [CrossRef]

13. Liu, T.Q.; Vieira, J.D.; Harries, K.A. Lateral torsional buckling and section distortion of pultruded GFRP I-sections subject to flexure. Compos. Struct. 2019, 225, 111151. [CrossRef]

14. Shan, L.; Qiao, P. Flexural-torsional buckling of fiber-reinforced plastic composite open channel beams. Compos. Struct. 2005, 68, 211-224. [CrossRef] 
15. Doan, Q.H.; Thai, D. materials A Numerical Study of the Effect of Component Dimensions on the Critical Buckling Load of a GFRP Composite Strut under Uniaxial Compression. Materials 2020, 13, 931. [CrossRef] [PubMed]

16. Hashem, Z.A.; Yuan, R.L. Short vs. long column behavior of pultruded glass-fiber reinforced polymer composites. Constr. Build. Mater. 2001, 15, 369-378. [CrossRef]

17. Cardoso, D.C.T.; Harries, K.A.; Batista, E.D.M. Compressive strength equation for GFRP square tube columns. Compos. Part B Eng. 2014, 59, 1-11. [CrossRef]

18. Puente, I.; Insausti, A.; Azkune, M. Buckling of GFRP columns: An empirical approach to design. J. Compos. Constr. 2006, 10, 529-537. [CrossRef]

19. Laudiero, F.; Minghini, F.; Tullini, N. Buckling and postbuckling finite-element analysis of pultruded FRP profiles under pure compression. J. Compos. Constr. 2014, 18, 04013026. [CrossRef]

20. Cintra, G.G.; Cardoso, D.C.T.; Vieira, J.D. Parameters affecting local buckling response of pultruded GFRP I-columns: Experimental and numerical investigation. Compos. Struct. 2019, 222, 110897. [CrossRef]

21. Selvaraj, M.; Kulkarni, S.M.; Rameshbabu, R. Performance Analysis of a Overhead Power Transmission Line Tower Using Polymer Composite Material. Procedia Mater. Sci. 2014, 5, 1340-1348. [CrossRef]

22. Selvaraj, M.; Kulkarni, S.M.; Babu, R.R. Structural evaluation of FRP Pultruded Sections in overhead transmission line Towers. Int. J. Civ. Struct. Eng. 2012, 2, 943-949. [CrossRef]

23. Balagopal, R.; Prasad Rao, N.; Rokade, R.P. Investigation on Buckling Behaviour of GFRP Angle Sections with Bolted Connections in Lattice Towers. J. Inst. Eng. Ser. A 2020, 101, 327-342. [CrossRef]

Publisher's Note: MDPI stays neutral with regard to jurisdictional claims in published maps and institutional affiliations. 